\title{
Azides and Nitriles in Palladium-Catalyzed Decarboxylative Allylation
}

Metal-Catalyzed Asymmetric

Synthesis and

Stereoselective

Reactions

\section{Key words}

allylic alkylation

palladium

azides

nitriles
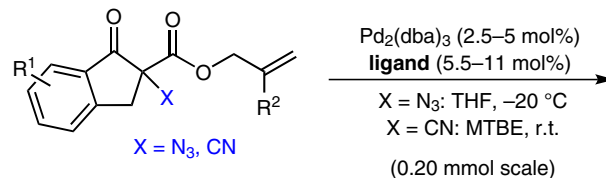

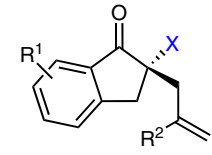

20 examples up to $98 \%$ yield

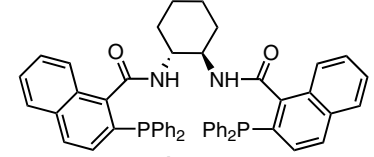

ligand<smiles>C=CC[C@]1(N)Cc2cc(OC)ccc2C1=O</smiles>
$86 \%$ yield $87 \%$ ee<smiles>C=CC[C@]1(N)Cc2c(Br)cccc2C1=O</smiles>
$85 \%$ yield $87 \%$ ee<smiles>C=C(C)C[C@]1(N)Cc2ccc(Cl)cc2C1=O</smiles>

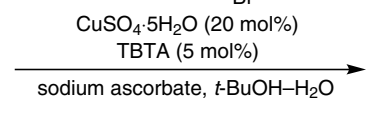

$\mathrm{Ph}_{3} \mathrm{P}, \mathrm{THF}, 0^{\circ} \mathrm{C}$ then $\mathrm{H}_{2} \mathrm{O}$

Modifications of the obtained products:

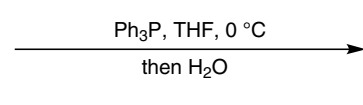<smiles>C=C(C)C[C@@]1(N)Cc2cc(Br)ccc2C1=O</smiles><smiles>C=C(C)C[C@]1(N)Cc2ccc(C(F)(F)F)cc2C1=O</smiles><smiles>C=C(C)C[C@]1(C#N)Cc2ccccc2C1=O</smiles><smiles>C=C(C)C[C@]1(N)Cc2ccc(F)cc2C1=O</smiles>

$81 \%$ yield $78 \%$ ee<smiles>C=C(C)C[C@]1(N)Cc2cc(Br)ccc2C1=O</smiles>

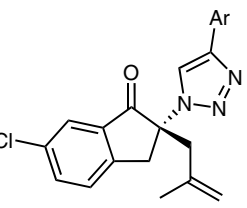

$94 \%$ yield

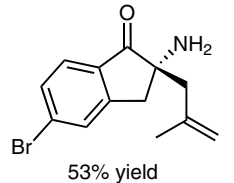

Significance: Homoallylic azides and cyanides are synthesized in enantioenriched form through a palladium-catalyzed decarboxylative allylation on indanones. These functional groups had seen little $(\mathrm{CN})$ to no $\left(\mathrm{N}_{3}\right)$ reported use in the title reaction.
Comment: The products are obtained in very good yield and mostly with high enantioselectivity. The starting materials can be synthesized in one step from the corresponding $\beta$-keto esters using hypervalent iodine reagents developed in the authors' laboratories.

SYNFACTS Contributors: Mark Lautens, Thomas Johnson 